\title{
Incidence of acute myocardial infarction in the Spanish epic cohort
}

\section{Incidencia de infarto agudo de miocardio en la cohorte EPIC España}

\author{
N. Larrañaga ${ }^{1,2}$, C. Moreno ${ }^{3,2,4}$, M. Basterretxea ${ }^{1,2}$, P. Marín ${ }^{3}$, M. D. Chirlaque ${ }^{5,2}$, \\ P. Amiano ${ }^{1,2}$, J. Castilla ${ }^{3,2}$, M. Dorronsoro ${ }^{1,3}$, J. R. Quirós ${ }^{6}$, M. J. Sánchez ${ }^{7,2}$, \\ E. Ardanaz ${ }^{3,2}$, A. Barricarte ${ }^{3,2}$, C. Navarro ${ }^{5,2}$, M. J. Tormo ${ }^{5,2}$, C. Martínez ${ }^{6,2}$, \\ T. Berenguer ${ }^{8}$, A. Agudo ${ }^{8}$, C. A. González
}

\begin{abstract}
Background. There is some evidence that Mediterranean diet reduces risk of ischemic heart disease, and this is to be investigated in the Spanish cohort of the European Prospective Investigation into Cancer and Nutrition (EPIC). In this paper we present the incidence of acute myocardial infarction (AMI) in four EPIC Spanish cohorts.

Method. Incidence cases were ascertained in EPIC cohort during the follow up period (from recruitment to the end of 2004), by means of self-report questionnaires, hospital morbidity and mortality registries, and population AMI registries. Analysis was restricted to aged 45 to 74 . The present study included data from 13,704 women and 19,410 men, after excluding a priori participants with prevalent AMI. Age standardized incidence rate for each cohort was estimated and compared with the available population rates.

Results. The Median duration of follow-up was 9.3 years, yielding a total of 297,704 person-years. 391 men and 99 women presented AMI in the four cohorts studied. Age standardized AMI rates in men of the EPIC cohorts go from the lowest 302 (CI: 268-335) per 100.000 person-year of Gipuzkoa to the highest 330 (CI: 293-367) of Navarra. Women in Navarra presented the lowest AMI incidence with 60 (CI: 43-77) per 100,000 and the highest was observed in Murcia (114, CI: 91-137). The AMI incidence in all EPIC centres are close to the population incidence rates and in any case these are within the EPIC 95\% CI. Conclusions. The comparison of incidence in EPIC with population rates shows very good agreement for acute myocardial infarction.
\end{abstract}

Key words. Ischemic heart disease. EPIC. Incidence rate. Myocardial infarction.

Abbreviations. EPIC: European Investigation into Cancer and Nutrition. AMI: Acute Myocardial Infarction. CHD: Coronary Heart Disease. MONICA: Monitoring trends and determinants of Cardiovascular disease. IBERICA: Investigación Búsqueda Específica y Registro de Isquemia Coronaria Aguda (Specific Search, Investigation and Registry of Acute Ischemic Coronary Disease. ASR: Age Standardized rates.

\section{RESUMEN}

Antedecentes. Existen evidencias que sugieren que la dieta mediterránea reduce el riesgo de enfermedad cardiaca isquémica y esta asociación va a ser investigada en la cohorte española del "Estudio europeo sobre cáncer y nutrición" (EPIC). En este artículo se presenta la incidencia de infarto agudo de miocardio (IAM) en 4 de las cohortes españolas. Método. Los casos incidentes de IAM fueron identificados en la cohorte EPIC durante el periodo de seguimiento (de reclutamiento a finales de 2004), mediante un cuestionario autorreportado, el registro de altas hospitalarias y de mortalidad y registros poblacionales de IAM. El análisis se centró en el grupo de 45 a 74 años de edad. El estudio incluyó cuatro cohortes compuestas de 13.704 mujeres and 19.410 hombres, tras la exclusión a priori de participantes con IAM prevalentes. Se estimó la tasa de incidencia ajustada por edad para cada cohorte, y se comparó con las tasas poblacionales disponibles.

Resultados. La duración mediana del seguimiento fue de 9,3 años, que aportó un total de 297.704 personas-año. 391 hombres and 99 mujeres presentaron IAM en las 4 cohortes estudiadas. Las tasas ajustadas por edad de IAM, en hombres, en las cohortes EPIC se movieron entre los 302 (CI 268-335) casos por 100.000 personas-año de Gipuzkoa, la menor tasa observada, hasta los 330 (CI: 293-367) de Navarra. Las mujeres navarras presentaron las tasas más bajas de IAM con unas cifras de 60 (CI: 43-77) casos por 100.000 mientras que las mujeres murcianas presentaron las tasas más altas (114, CI: 91-137). La incidencia de IAM en todas las regiones EPIC fué similar a la incidencia poblacional conocida de dichas regiones, o bien se mantienen dentro del intervalo de confianza la $95 \%$.

Conclusiones. La incidencia de la cohorte EPIC muestra gran concordancia con las tasas poblaciones disponibles para el IAM.

Palabras clave. Enfermedad cardiaca isquémica. EPIC. Tasa de incidencia. Infarto de miocardio
1. Public Health Department of Guipúzcoa. Basque Government. San Sebastian. Spain.

2. CIBER de Epidemiologia y Salud Pública (CIBERESP). Spain.

3. Public Health Institute of Navarra. Pamplona. Spain.

4. University of Barcelona.

5. Department of Epidemiology. Murcia Health Council. Murcia. Spain.

6. Public Health and Health Planning Directorate. Asturias. Spain.

7. Escuela Andaluza de Salud Pública. Granada. Spain.

8. Department of Epidemiology. Catalan Institute of Oncology. Barcelona. Spain.
Recepción: 3 de octubre de 2008

Aceptación provisional: 12 de marzo de 2009

Aceptación definitiva: 13 marzo de 2009

\section{Correspondencia:}

Nerea Larrañaga

Subdirección de Salud Pública de Gipuzkoa

Avda. de Navarra, 4

20013 Donostia-Gipuzkoa

E-mail: epidem3-san@ej-gv.es 


\section{INTRODUCTION}

Although coronary heart disease (CHD) causes $11,2 \%$ and $9,6 \%$ of deaths in Spain $^{1}$, mortality rates of this country are along with French rates the lowest in Europe $^{2,3}$. Incidence data was scarce in Spain due to the difficulty of recording out-ofhospital fatal acute myocardial infarction (AMI) cases, and the only population data came from two neighbouring areas in the north-eastern part of the country. A prospective population registry in seven Spanish regions in 1997-1998 showed that AMI cumulative incidence and mortality rates are low compared with other industrialized countries but vary considerably among different regions in a Mediterranean country like Spain $^{4-7}$. Data on incidence trends is also scarce ${ }^{7}$ and non conclusive. One study showed an increase in coronary heart disease in Spanish men ${ }^{8}$ while in a more recent study, a decrease in men below the age of 65 was observed ${ }^{9}$. A decline in incidence and mortality have also been described in some European regions ${ }^{10-13}$.

Known causes of CHD (smoking habits, and blood cholesterol and blood pressure levels) account for much of the variation in disease rates, and their control has lead to substantial improvements in disease prevention ${ }^{14}$ but this does not completely explain geographical variability ${ }^{15}$. The low incidence of CHD in Mediterranean countries has been partly ascribed to dietary habits and studies on this topic have become more frequent ${ }^{16-18}$. However, there is no direct evidence, from large cohort studies, that a Mediterranean diet reduces the risk of ischemic heart disease. So it has been proposed as the main objective of the Spanish branch of the EPIC-Heart ${ }^{19}$, to examine the relationship between the adherence to a pattern of Mediterranean diet and the incidence of acute myocardial infarction and other forms of ischemic heart disease. This project will allow standardized and valid classification of cardiovascular event diagnoses for coronary heart disease. In this paper we present the incidence of fatal and non-fatal AMI in four EPIC Spanish cohorts and results are compared to population rate estimates in the same regions.

\section{METHODS}

\section{Study population}

The EPIC Spanish cohort includes 41,446 subjects (15,632 men and 25,808 women) 29 to 69 years old, recruited between 1992 and 1996. They came from five Spanish regions, three from the north, Asturias (3,085 men and 5,456 women), Gipuzkoa (4,158 men and 4,259 women) and Navarra (3,908 men and 4,176 women) and two from the south, Murcia (2,685 men and 5,831 women) and Granada (1,760 men and 5,961 women). The participants were healthy volunteers from different social sectors, selected from urban and rural areas. The majority were active blood donors and in lesser amount industrial workers, civil servants or general population. Each subject provided information on dietary habits and other lifestyle factors; anthropometric measurements and blood sample were also taken at recruitment. Baseline questionnaires in all centres recorded self-reported histories of AMI including the reported age at onset of such diagnoses.

The participants were informed that all the information given was confidential and that the databases were registered at the Spanish Data Protection Authority as stipulated by law. All participants provided written informed consent regarding the use of patient identifiable information.

EPIC-Heart is the cardiovascular component of the European Investigation into Cancer and Nutrition (EPIC) ${ }^{20,21}$. The overall objective of EPIC-Heart is to make the best possible use of the data and biological samples available in EPIC in order to advance understanding about the separate and combined influences of lifestyle (especially dietary), environmental, metabolic and genetic factors in the development of cardiovascular diseases, including coronary disease, stroke and other vascular diseases ${ }^{19}$. The Spanish EPIC-Heart project has ascertained and validated all fatal and non-fatal incident cases of coronary heart disease.

\section{Coronary endpoint and follow-up period}

Different methods have been used in each centre to identify incident non-fatal and 
fatal coronary events, including self-report questionnaires, queries of medical records, linkage with hospital morbidity and mortality registries, and population AMI registries (Table 1). The case ascertainment in Granada was done using a self-reported questionnaire three years after recruitment and hospital AMI register, but neither of them covered the whole follow up period, nor the whole population, and they did not have access to hospital discharge registers, therefore, data from EPIC Granada was excluded.

Table 1. Method of coronary disease case ascertainment in EPIC-Spain, by centre.

\begin{tabular}{|c|c|}
\hline EPIC centre & Ascertainment Method \\
\hline Asturias & $\begin{array}{l}\text { Telephone questionnaires } 3 \text { years after recruitment, and every } 2 \text { years up to the end of follow up } \\
\text { Hospital discharge records (1993-2004), involving ICD-9 diagnostic codes } 410-414 \text { and procedu- } \\
\text { res codes } 36.0,36.1 \\
\text { Mortality registry (1993-2004) involving ICD-9 codes } 410-414 \text { or ICD-10 codes I } 20-125\end{array}$ \\
\hline Navarra & $\begin{array}{l}\text { Telephone questionnaires } 3 \text { years after recruitment. } \\
\text { Hospital discharge records (1996-2004) involving ICD-9 codes } 410-414 \text { and procedures codes } \\
36.0,36.1 \\
\text { Population AMI registry (1997-1998) } \\
\text { Mortality registry (1993-2004) involving ICD-9 codes } 410-414 \text { or ICD-10 codes } 120-125\end{array}$ \\
\hline Gipuzkoa & $\begin{array}{l}\text { Telephone questionnaires } 3 \text { years after recruitment. } \\
\text { Postal questionnaire in } 2003 \text {. } \\
\text { Hospital discharge records (1993-2004) involving ICD-9 codes } 410-414 \text { and procedures codes } \\
36.0,36.1 \\
\text { Population AMI registry (1997-2000) } \\
\text { Mortality registry (1993-2004) involving ICD-9 codes } 410-414 \text { or ICD-10 codes } 120-125\end{array}$ \\
\hline Murcia & $\begin{array}{l}\text { Telephone questionnaires } 3 \text { years after recruitment. } \\
\text { Hospital discharge records (1996-2004) involving ICD-9 codes } 410-414 \text { and procedures codes } \\
36.0,36.1 \\
\text { Population AMI registry (1997-1998) } \\
\text { Mortality registry (1993-2004) involving ICD-9 codes } 410-414 \text { or ICD-10 codes } 120-125\end{array}$ \\
\hline
\end{tabular}

Each event was investigated through the abstraction and review of patients' medical records and medico-legal necropsy reports by a team of nurses and physician. This team was trained for event registration by qualified personal. Non fatal case validation was based on symptoms, enzymes and electrocardiograms. Fatal cases were validated on past coronary history and necropsy findings. Events were classified into three diagnostic categories: (i) fatal and non-fatal definite, (ii) fatal and nonfatal possible, (iii) fatal coronary events with insufficient information according to internationally agreed criteria ${ }^{22-24}$. MONICA (Monitoring trends and determinants of Cardiovascular disease) definition 3 for coronary events was used in the main analysis, considering the new definition ${ }^{24}$ for cases identified from 2000 to 2004 . Previous angina or infarctions were recorded and only first AMI incident cases were included in the analyses.

Information on the vital status of participants was obtained from mortality registries (National Statistical Institute) and by active follow-up. Participants were classified as alive at last follow-up and dead. Cause of death was defined based on International Classification of Disease: coronary heart disease (ICD-9; 410-414; ICD-10 I20-I25).

All participants were followed up from recruitment to the end of year 2004 .

\section{Statistical analysis}

Age adjusted prevalence of the main risk factors at recruitment were obtained for each of the four cohorts. Incidence analyses were restricted to those aged 45 
to 74 , because events were rare in younger participants, and the cohort did not comprise data for older individuals. Therefore, the present study was based on data from 33,114 subjects, 13,704 women and 19,410 men, after excluding a priori participants with prevalent AMI cases at baseline examination.

Using incident cases ascertained in EPIC cohort in the period 1993 to 2004, age standardized incidence rates (ASR) were computed using the direct method, and their 95\% confidence intervals (CI), for the four EPIC Spanish centres, using 5-years categories of age. Calculation of standard error of the ASR was estimated by the Poisson approximation ${ }^{25}$. The (truncated) standard European population was used as reference.

Rates from the EPIC study were compared to ASR from population rates avail- able in 3 of the EPIC centres -IBERICA (The Investigación Búsqueda Específica y Registro de Isquemia Coronaria Aguda) Gipuzkoa (1997-2000), IBERICA-Navarra (1997-1998), and IBERICA-Murcia (1997-1998)-, using 5 -years age groups in the same age interval.

All analyses were performed using SAS Statistical Software (version 9.1, SAS Institute, Cary, NC).

\section{RESULTS}

A description of the main cardiovascular risk factor for each of the four cohorts is presented in table 2 and 3. Significantly lower prevalence of obesity is seen in men of Gipuzkoa with the highest diabetes prevalence in men of Murcia and Gipuzkoa. In women of Murcia, a significantly higher prevalence of obesity, hyperlipidemia, hypertension and diabetes was observed.

Table 2. Distributions (\%) of classical cardiovascular risk factors in the EPIC-Spain cohort (men age 35-69) as reported at recruitment.

\begin{tabular}{lcccc}
\hline \multicolumn{1}{c}{ Characteristics } & Asturias & Gipuzkoa & Murcia & Navarra \\
\hline Obese $(\mathrm{BMI}) \geq 30$ & 31.4 & 24.8 & 31.5 & 34.5 \\
\hline Smoker & 36.8 & 42.3 & 37.6 & 44.3 \\
\hline Hyperlipidemia & 30.5 & 31.9 & 28.9 & 24.8 \\
\hline Hypertension & 22.7 & 21.5 & 26.0 & 25.7 \\
\hline Diabetes & 3.0 & 7.0 & 7.1 & 3.7 \\
\hline
\end{tabular}

All $\mathrm{p}$ values $<0.000$

Table 3. Distributions (\%) of classical cardiovascular risk factors in the EPIC-Spain cohort (women age 35-69) as reported at recruitment.

\begin{tabular}{lcccc}
\hline \multicolumn{1}{c}{ Characteristics } & Asturias & Gipuzkoa & Murcia & Navarra \\
\hline Obese $(\mathrm{BMI}) \geq 30$ & 30.4 & 21.5 & 35.3 & 25.6 \\
\hline Smoker & 17.0 & 13.9 & 14.5 & 18.8 \\
\hline Hyperlipidemia & 12.7 & 12.8 & 17.0 & 9.5 \\
\hline Hypertension & 16.9 & 14.1 & 20.9 & 14.8 \\
\hline Diabetes & 1.4 & 3.0 & 4.8 & 1.3 \\
\hline
\end{tabular}

All $\mathrm{p}$ values $<0.000$ 
The median follow-up time was of 9.9 years with a maximum of 12.2 years for the 33,114 cohort members, yielding a total of 297,704 person-years. During the follow up period, 391 men and 99 women, aged 45-74, presented AMI in the 4 EPIC Spanish cohorts studied. The mean (SD) age at baseline was 50 (7.1) in men and 47 (8.1) in women and the mean age at diagnosis for the cases was 59 (7.2) and 62 (7.5) for men and women respectively.

Age standardized AMI rates in men of the EPIC cohorts goes from the lowest 301.7 per 100.000 person-year in the Gipuzkoa cohort to the highest 329.8 in Navarra (Table 4 ), while women (Table 5) of Navarra presented the lowest ASR (59.8), with the highest being that of Murcia cohort (113.8).

Table 4. Centre-specific cohort information, crude incidence rates, and age standardized incidence rates of acute myocardial infarcts in EPIC-Spain men age 45-74.

\begin{tabular}{lcccccr}
\hline $\begin{array}{c}\text { EPIC } \\
\text { Centre }\end{array}$ & $\begin{array}{c}\text { Cohort Size } \\
\text { (n) }\end{array}$ & $\begin{array}{c}\text { Age at baseline } \\
\text { Mean (range) }\end{array}$ & $\begin{array}{c}\text { Person } \\
\text { Year }\end{array}$ & $\begin{array}{c}\text { No. } \\
\text { Cases }\end{array}$ & $\begin{array}{c}\text { Crude } \\
\text { Rate }\end{array}$ & ASR (95\%Cl) \\
\hline Asturias & 3,063 & $49.9(34-67)$ & 29,466 & 92 & 312 & $325(285-364)$ \\
\hline Navarra & 3,879 & $50.1(35-67)$ & 37,997 & 117 & 308 & $330(293-367)$ \\
\hline Gipuzkoa & 4,120 & $50.5(34-66)$ & 40,007 & 117 & 292 & $302(268-335)$ \\
\hline Murcia & 2,642 & $50.0(35-69)$ & 24,665 & 65 & 264 & $303(257-349)$ \\
\hline
\end{tabular}

Table 5. Centre-specific cohort information, crude incidence rates, and age standardized incidence rates of acute myocardial infarcts in EPIC-Spain women age 45-74.

\begin{tabular}{lcccccr}
\hline $\begin{array}{c}\text { EPIC } \\
\text { Centre }\end{array}$ & $\begin{array}{c}\text { Cohort Size } \\
(\mathbf{n})\end{array}$ & $\begin{array}{c}\text { Age at baseline } \\
\text { Mean (range) }\end{array}$ & $\begin{array}{c}\text { Person } \\
\text { Year }\end{array}$ & $\begin{array}{c}\text { No. } \\
\text { Cases }\end{array}$ & $\begin{array}{c}\text { Crude } \\
\text { Rate }\end{array}$ & ASR (95\%Cl) \\
\hline Asturias & 5,292 & $47.4(34-67)$ & 44,965 & 25 & 56 & $71(53-88)$ \\
\hline Navarra & 4,149 & $48.2(34-66)$ & 36,179 & 18 & 50 & $60(43-77)$ \\
\hline Gipuzkoa & 4,252 & $47.7(34-66)$ & 37,364 & 16 & 43 & $69(48-89)$ \\
\hline Murcia & 5,717 & $47.8(33-69)$ & 47,062 & 40 & 85 & $114(91-137)$ \\
\hline
\end{tabular}

Figures 1 and 2 show gender and centre specific EPIC standardized incidence rates with $95 \% \mathrm{CI}$ and population rates for AMI. As compared with men in the reference group (IBERICA), the AMI incidence rates for men in all EPIC centres, are close to the population incidence rates from 1997-1998 or 1997-2000 and in any case the population rates are within the EPIC 95\% CI.

On the other hand, women from the Gipuzkoa and Asturias EPIC cohorts show very similar AMI incidence rates, which lie within of the ASR population rates of the northern references (IBERICA Gipuzkoa and Navarra). Women from the Navarra EPIC cohort presented a lower AMI incidence rates than the population registry of this region during 1997-1998. In the southern region, women rate from the EPIC-Murcia cohort is above the population rate. In any case, the population AMI rates for women are within the EPIC $95 \%$ of any of the three centres available.

\section{DISCUSSION}

Spain has shown an AMI incidence close to those of other southern European Mediterranean countries, and much lower than the average WHO-MONICA study ${ }^{4}$ and so has the EPIC cohort. The Spanish EPICHeart project has ascertained and validated all fatal and non-fatal incident cases of 
CHD by means of international agreed criteria. Though it is necessary to take into account that the EPIC Spanish cohort is not a random representative sample of the population from which they were selected. On the other hand, advancing diagnostic technology, over the last years of follow up period, has providee information that is more sensitive and specific in detecting even minor myocardial cell damage, and this new case definition has been used in this study. But above all the limitation, the EPIC-cohort incidence data shown in the study period suggests a similar incidence to that of the population and does confirm the external validity of the information in all cohorts studied. This study also adds credible estimation of incidence rate for Asturias, for which population registry of AMI is not available.

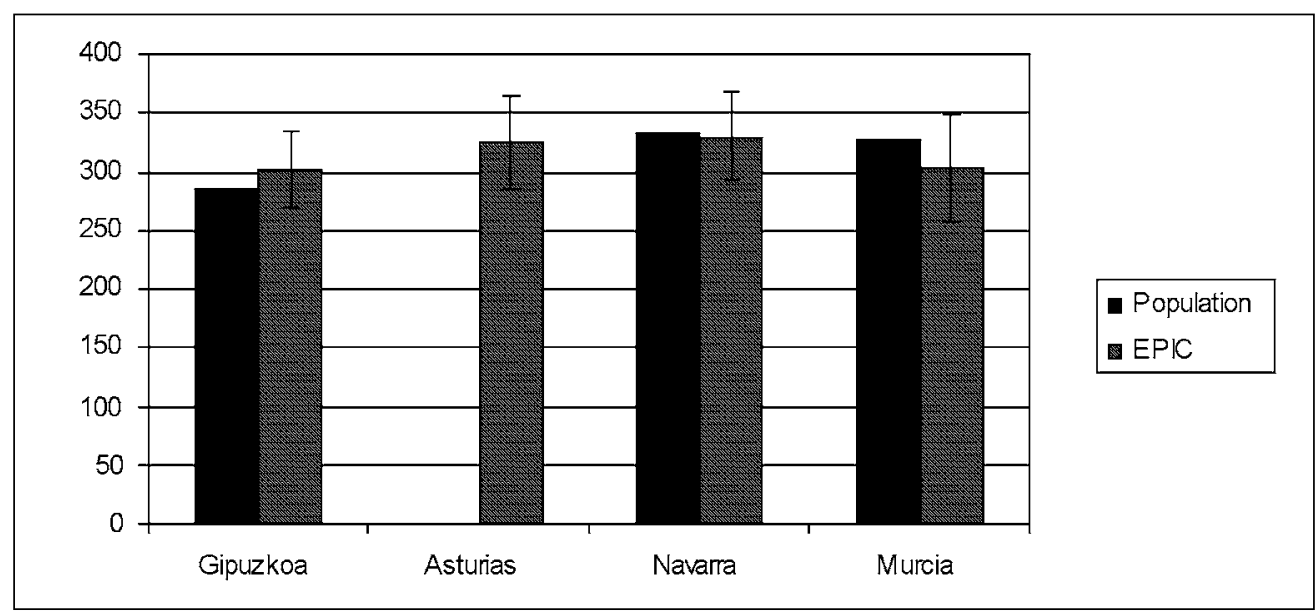

Figure 1. Age standardized incidence rates (95\% CI) of acute myocardial infarcts, in EPIC Spain and from IBERICA (population) by centre, men aged 45-74.

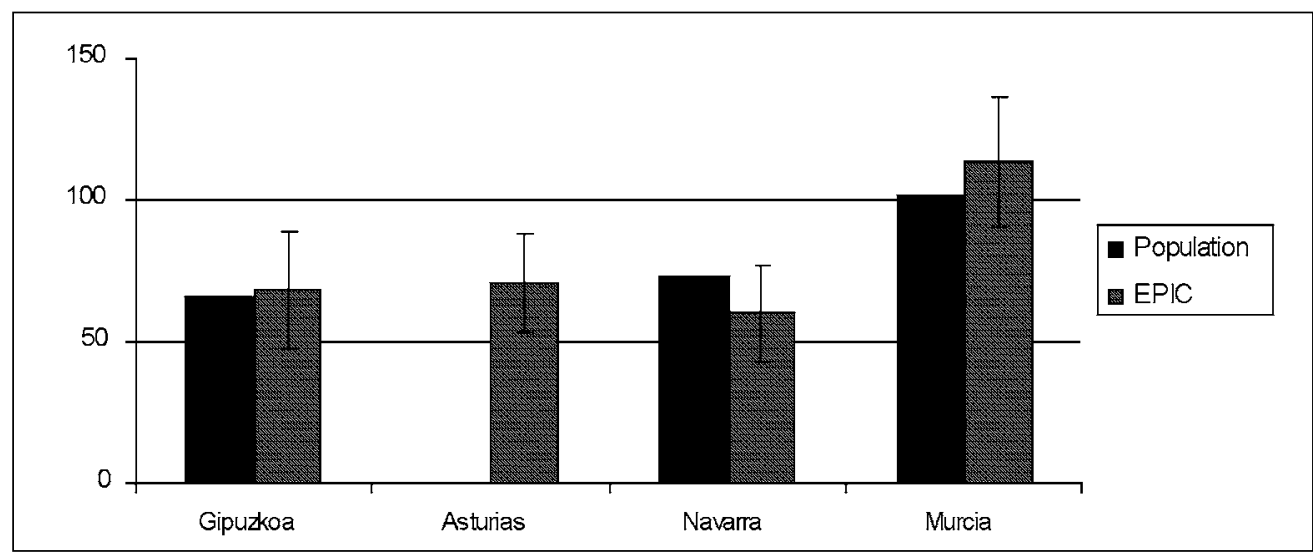

Figure 2. Age standardized incidence rates (95\% CI) of acute myocardial infarcts, in EPIC Spain and IBERICA (population) by centre, women aged 45-74. 
Data presented in this paper shows some variability in the four EPIC cohorts, and also between the regions where they come from. Men from the northern EPIC cohorts, especially from Asturias and Navarra showed the highest incidence of AMI, but the real difference was marked by women from Murcia, with the highest incidence rates of the four cohorts. Some descriptive studies, within the EPIC Spanish cohort, have also shown great variability in some risk factors such as fish intake, physical activity, body mass index, alcohol consumption and prevalence of smokers ${ }^{26}$. Thus, women of Murcia presented at recruitment the highest proportion of obesity, hypertension, hyperlipidemia, diabetes. A higher prevalence of obesity has been also been observed in the population of Murcia as compared to the other three regions ${ }^{27}$ included in this study.

There is regional variability in ischemic heart disease mortality as well as in incidence within different Spanish regions, and there have been described differences as well in management and prognosis of coronary patients ${ }^{28,29}$ Mortality statistics $^{1}$ in the EPIC regions show the highest rates for Murcia and Asturias in both men and women and the lowest for Gipuzkoa and Navarra. A large incidence study presented by Marrugat et $\mathrm{al}^{5}$ shows regional variability within 7 Spanish regions, Murcia showing incidence rates significantly over the average, for both men and women. Navarra' rates were under the average in men, and the Basque Country's were also lower for both men and women. This phenomenon has also been described by Lang et $\mathrm{al}^{2}$, although in France, the North-South gradient observed in mortality was found to be much more pronounced for case fatality than for incidence.

The comparison of ASR in EPIC with population rates shows very good agreement for AMI, in both men and women in all EPIC cohorts studied. Higher rates, though not statistically significant, were observed in EPIC Gipuzkoa cohort, as compared with their population statistics, for both men and women, and for women in the EPIC Murcia. On the other hand, men from EPIC Murcia and women from the EPIC Navarra presented lower incidence rates, though not statistically significant, than their population references.

The lower incidence rates as compared to their population data in some of the cohorts could be explained by some selection processes in the recruitment of EPIC participants, possibly related to socio-economic factors and/or the high proportion of blood donors in the EPIC cohorts, $100 \%$ in $\mathrm{Na}$ varra EPIC cohort, $89 \%$ in Asturias, $75 \%$ in Gipuzkoa and 65\% in Murcia. In this sense, prevalence of smoking in the EPIC cohorts is likely to be lower than the general populations ${ }^{26}$.

In conclusion, the AMI incidence observed in the EPIC Spanish cohort is compatible to the one expected, and shows the regional variability that has also been described in incidence and risk factors in the regions they came from. This data will allow future analysis in relation to diet and other genetic and environmental factors, and will add more evidence to previously published information.

\section{Acknowledgements}

This study was funded by a research Grant (FIS) of the Spanish Ministry of Health; the ISCIII CIBER en Epidemiología y Salud Pública in Spain and RETIC (RD06/0020) RETICC C03/10, Spanish Regional Governments of Andalusia, Asturias, Basque Country, Murcia and Navarra and the Catalan Institute of Oncology. We are especially indebted to Izar Unanue and Fuensanta Cuenca, for their contribution to data collection, and all the staff of collaborating hospitals, community physicians, local and central Mortality Registry.

\section{REFERENCE LIST}

1. Boix Mr, Aragones SN, Medrano Albero MJ. Tendencias en la mortalidad por cardiopatía isquémica en 50 provincias españolas. Rev Esp Cardiol 2003 Sep; 56: 850-856.

2. Lang T, Ducimetiere P, Arveiler D, Amouyel P, FERrieres J, Ruidavets JB et al. Trends and geographical disparities in coronary heart disease in France: are results concordant when different definitions of events are used? Int $\mathrm{J}$ Epidemiol 1999 Dec; 28: 1050-1058.

3. Marqués-Vidal P, Ruidavets JB, Cambou JP, FerRIERES J. Incidence, recurrence, and case fatal- 
ity rates for myocardial infarction in southwestern France, 1985 to 1993. Heart 2000 Aug; 84: 171-175.

4. Tunstall-Pedoe H, Kuulasmaa K, Mahonen M, Tolonen H, Ruokokoski E, Amouyel P. Contribution of trends in survival and coronary-event rates to changes in coronary heart disease mortality: 10-year results from 37 WHO MONICA project populations. Monitoring trends and determinants in cardiovascular disease. Lancet 1999 May 8; 353 (9164): 1547-1557.

5. Marrugat J, Elosua R, Aldasoro E, Tormo MJ, Vanaclocha H, Segura A et al. Regional variability in population acute myocardial infarction cumulative incidence and mortality rates in Spain 1997 and 1998. Eur J Epidemiol 2004 Sep; 19: 831-839.

6. Moreno C, Turumbay J, Garcia V, Ezpeleta I, De Los AE, Manrique A et al. El infarto de miocardio en la población de 25-74 años de Navarra. Incidencia, letalidad y tratamiento en el periodo 1997-98. Estudio IBERICA. An Sist Sanit Navar 2002 May; 25: 155-156.

7. Marrugat J, Elosua R, Marti H. Epidemiología de la cardiopatía isquémica en España: estimación del número de casos y de las tendencias entre 1997 y 2005. Rev Esp Cardiol 2002 Apr; 55: 337-346.

8. Sans S, Puigdefábregas A, Pluzie G, Monterde D, BALAGUER-VINTRó I. Increasing trends of acute myocardial infarction in Spain: the MONICACatanolia Study. European Heart Journal 2005; 26: 505-515.

9. Gil M, Marti H, Elosua R, Grau M, Sala J, Masia $\mathrm{R}$ et al. Análisis de la tendencia en la letalidad, incidencia y mortalidad por infarto de miocardio en Girona entre 1990 y 1999. Rev Esp Cardiol 2007; 60: 349-356.

10. Murphy NF, Macintyre K, Capewell S, Stewart S, Pell J, Chalmers J et al. Hospital discharge rates for suspected acute coronary syndromes between 1990 and 2000: population based analysis. BMJ 2004 Jun 12; 328 (7453): 1413-1414.

11. Abildstrom SZ, Rasmussen S, Rosen M, Madsen M. Trends in incidence and case fatality rates of acute myocardial infarction in Denmark and Sweden. Heart 2003 May; 89: 507-511.

12. LAMPe FC, Morris RW, WalKer M, SHAPER AG, WhinCUP PH. Trends in rates of different forms of diagnosed coronary heart disease, 1978 to 2000 : prospective, population based study of British men. BMJ 2005 May 7; 330 (7499): 1046.

13. Rosen M, Alfredsson L, Hammar N, Kahan T, Spetz CL, Ysberg AS. Attack rate, mortality and case fatality for acute myocardial infarction in Sweden during 1987-95. Results from the national AMI register in Sweden. J Intern Med 2000 Aug; 248: 159-164.
14. Beaglehole R, Magnus P. The search for new risk factors for coronary heart disease: occupational therapy for epidemiologists? Int $\mathrm{J}$ Epidemiol 2002 Dec; 31: 1117-1122.

15. Kuulasmaa K, Tunstall-Pedoe H, Dobson A, Fortmann S, SAns S, Tolonen $\mathrm{H}$ et al. Estimation of contribution of changes in classic risk factors to trends in coronary-event rates across the WHO MONICA Project populations. Lancet 2000 Feb 26; 355 (9205): 675-687.

16. Fernández-Jarne E, Martínez-Losa E, Prado-Santamaría M, Brugarolas-Brufau C, Serrano-MarTíNEZ M, MARTínez-GonzÁLEZ MA. Risk of first non-fatal myocardial infarction negatively associated with olive oil consumption: a case-control study in Spain. Int J Epidemiol 2002 Apr; 31: 474-480.

17. Martínez-GonzÁlez M, Fernádez-Jarne E, SerranoMARTínez $\mathrm{M}$ et al. Mediterranean diet and reduction in the risk of a first acute myocardial infarction: an operational healthy dietary score. Eur J Epidemiol 2002 Aug; 41: 153-160.

18. Estruch R, Martínez-GonzÁlez MA, Corella D, Salas-Salvado J, Ruiz-Gutiérrez V, Covas MI et al. Effects of a Mediterranean-style diet on cardiovascular risk factors: a randomized trial. Ann Intern Med 2006 Jul 4; 145: 1-11.

19. Danesh J, Saracci R, Berglund G., Fesdens E, Overvad K, Panico $\mathrm{S}$ et al. EPIC-Heart: The cardiovascular component of a prospective study of nutritional, lifestyle and biological factors in 520,000 middle-aged participants from 10 European countries. Eur J Epidemiol 2007; 22: 129-141.

20. Riвoli E. Nutrition and cancer: background and rationale of the European Prospective Investigation into Cancer and Nutrition (EPIC). Ann Oncol 1992; 3: 783-791.

21. Riboli E, Hunt K, Slimani N, Ferrari P, Noral T, FAHEY M et al. European prospective investigation into cancer and nutrition (EPIC): study populations and data collection. Public Health Nutr 2002 Dec; 5 (6B): 1113-1124.

22. Tunstall-Pedoe $\mathrm{H}$, Kunlasmaa $K$, Amouyel $\mathrm{P}$, Arveiler D, Rajakangas AM, PajaK A. Myocardial infarction and coronary deaths in the World Health Organization MONICA Project. Registration procedures, event rates, and case-fatality rates in 38 populations from 21 countries in four continents. Circulation 1994 Jul; 90: 583-612.

23. Saloma V, Dobson A, Miettinen H, Rajakangas AM, KuUlasmaA K, for WHO MONICA. Mild myocardial infarction - a classification problem in epidemiologic studies. J Clin Epidemiol 1997 Jan; 50: 3-13.

24. Luepker RV, Apple FS, Christenson RH, Crow RS, Fortmann SP, Goff D et al. Case definitions for acute coronary heart disease in epidemiolo- 
gy and clinical research studies: a statement from the AHA Council on Epidemiology and Prevention; AHA Statistics Committee; World Heart Federation Council on Epidemiology and Prevention; the European Society of Cardiology Working Group on Epidemiology and Prevention; Centers for Disease Control and Prevention; and the National Heart, Lung, and Blood Institute. Circulation 2003 Nov 18; 108: 2543-2549.

25. Jensen OM, Parkin DM, MacLennan R, Muir CS, SkeEet RG. Registros de cáncer. Principios y métodos. Lyon: IARC; 1995. Publicaciones científicas n.o 95 .

26. Epic-spain.com. 2003 [updated 2006 Apr 04; cited 2007 apr 18]. Available from: http:// www.epic-spain.com
27. López-Bescos L, Cosin J, Elosua R, Cabades A, DE Los RM, Aros F et al. Prevalencia de angina $\mathrm{y}$ factores de riesgo cardiovascular en las diferentes comunidades autónomas de España: estudio PANES. Rev Esp Cardiol 1999 Dec; 52: 1045-1056.

28. Fiol M, Cabades A, Sala J, Marrugat J, Elosua R, VEGA G et al. Variabilidad en el manejo hospitalario del infarto agudo de miocardio en España. Estudio IBERICA (Investigación, Búsqueda Específica y Registro de Isquemia Coronaria Aguda). Rev Esp Cardiol 2001 Apr; 54: 443-452.

29. García J, Elosua R, Tormo Díaz MJ, Audicana UC, ZuRriaga O, SEgura A et al. Letalidad poblacional por infarto agudo de miocardio. Estudio IBERICA. Med Clin (Barc) 2003 Nov 8; 121: 606-612. 
